\title{
A New Type of Dual-phase Steel Sheet for Automobile Outer Body Panels*
}

\section{By Akihiko NISHIMOTO,** Yoshihiro HOSOYA** and Kazuhide NAKAOKA**}

\begin{abstract}
Synopsis
$A$ new type of cold rolled dual-phase steel sheet with good formability and dent-resistance has been developed for automobile outer body panels. The steel, basically a low carbon and manganese aluminum killed steel, is manufactured by means of hot rolling with high temperature coiling, cold rolling, and continuous annealing with water-quenching and tempering. The mechanical properties after temper rolling are characterized by yield strength lower than $24 \mathrm{~kg} / \mathrm{mm}^{2}$, total elongation larger than $40 \%$ and $\bar{r}$-value higher than 1.5. Moreover the steel sheet has not only high bake hardenability but also high anti-aging property.
\end{abstract}

\section{Introduction}

High strength steel sheets have been used as automotive material for improving safety and for saving fuel consumption by weight reduction. However, there are still various problems to be solved in order to expand the applications. Re-phosphorized steel sheets having tensile strength of $40 \mathrm{kgf} / \mathrm{mm}^{2}$ were generally believed to be the most feasible material for automobile outer body panels. But currently some automotive companies have discontinued the application on account of the surface strain which appear on the formed parts, and turned back to a lower strength material at the sacrifice of dent-resistance.

This paper presents a new approach to production of high strength cold rolled sheets to be used for outer body panels.

\section{Requirements of Mechanical Properties for Body Panels}

It has been established that the improvement of dent-resistance, which is the main subject in using high strength steel sheet for outer body panels, is achieved by increasing the yield strength of the panel, although increase in yield strength is accompanied by the occurrence of surface strain.

The yield strength of the panel is increased by work-hardening as a result of press forming. However, the amount of the strain by forming varies from one portion to another, and it is very small as shown in Fig. 1 .

Therefore, we can not expect the improvement of dent-resistance throughout the formed panel only by work-hardening. On the other hand, strain aging increases the yield strength of the panel at paint-baking. The sum of the work hardenability and bake hardenability should be considered.

Based on our experience in re-phosphorized steel sheets, we had set a following specification with respect to strength levels to achieve a good combination of press formability and dent-resistance:

Yield strength before stamping: less than $24 \mathrm{kgf} /$ $\mathrm{mm}^{2}$.

Yield strength after $2 \%$ straining and subsequent paint baking $\left(170^{\circ} \mathrm{C}\right.$ for $\left.20 \mathrm{~min}\right)$ : more than $30 \mathrm{kgf} / \mathrm{mm}^{2}$.

In addition to the strength level, $\bar{r}$-value, elongation, and anti-aging property should be taken into account. Higher $\bar{r}$-value is beneficial not only for deep-drawability, but also for the stretch-flangeability of sheared edge of $40 \mathrm{kgf} / \mathrm{mm}^{2}$ grade steel sheets, as shown in Fig. 2,1) as well as in the case of mild steel sheets. ${ }^{2)}$ We had considered from our experience in mild steel that the requirements for outer body panels are almost satisfied by a material with the $\bar{r}$-value of 1.5 and the total elongation of $40 \%$. As to the anti-

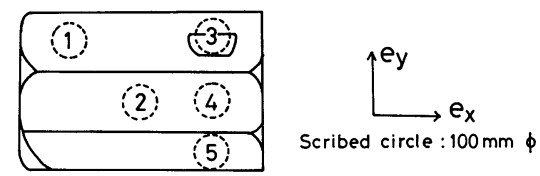

\begin{tabular}{|c|c|c|c|c|}
\hline \multirow{2}{*}{ Sample } & \multicolumn{2}{|c|}{$\begin{array}{c}\text { Re-phosphorized } \\
\text { steel }\end{array}$} & \multicolumn{2}{c|}{ Al-killed steel } \\
\hline \multirow{2}{*}{ Portion } & Strain $(\%)$ & \multicolumn{2}{c|}{ Strain $(\%)$} \\
\cline { 2 - 5 } & $e_{x}$ & $e_{y}$ & $e_{x}$ & $e_{y}$ \\
\hline 1 & 0.0 & 0.5 & -0.5 & 0.3 \\
\hline 2 & 0.0 & 0.9 & -0.5 & 0.4 \\
\hline 3 & 0.0 & 3.1 & -0.8 & 3.4 \\
\hline 4 & 0.0 & 1.8 & -0.5 & 1.4 \\
\hline 5 & 0.0 & 0.9 & -0.5 & 0.8 \\
\hline YS: & $24.1 \mathrm{kgf} / \mathrm{mm}^{2}$. & TS: $40.5 \mathrm{kgf} / \mathrm{mm}^{2}$. \\
** YS: & $17.3 \mathrm{kgf} / \mathrm{mm}^{2}$. & TS: $32.1 \mathrm{kgf} / \mathrm{mm}^{2}$.
\end{tabular}

Fig. 1. Strain distribution in a formed door outer panel.

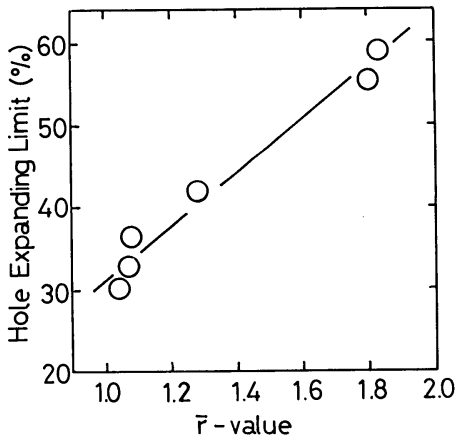

Fig. 2. Relation between $\bar{\gamma}$-value and hole expanding limit.

* Based on the paper presented to the symposium of the 100th ISIJ Meeting, October 1980, at Kyushu University, Fukuoka, (published in Tetsu-to-Hagané, 66 (1980), A201, in Japanese). English manuscript received April 24, 1980.

** Technical Research Center, Nippon Kokan K.K., Minamiwatarida-cho, Kawasaki-ku, Kawasaki 210. 
aging properties indispensable for preventing the stretcher strain, we had concluded from our experiences in the case of conventional low carbon steel sheet that the recovery of yield point elongation after an artificial aging treatment at $38^{\circ} \mathrm{C}$ for 8 days should be less than $0.5 \%$.

\section{Design of Manufacturing Process}

Imparting bake hardenability to steel is an effective way for strengthening of the panels that are subjected to paint-curing process. The bake hardenability can be imparted by leaving the solute carbon or nitrogen in the steel, but these interstitials are responsible for the enhancement of the susceptibility to strain at room temperature. Therefore we had decided to make use of the remarkable effect of dualphase structure to suppress an appearance of yield point elongation, while retaining solute carbon in lattice. ${ }^{3,4}$ )

Fortunately we can easily achieve the dual-phase structure from low Mn steels by using the waterquenching type continuous annealing line. With this method, we can expect higher $\bar{r}$-value by appropriate combinations of high temperature coiling in the hot rolled strip mill and high temperature annealing in the line. ${ }^{5)}$

\section{Experimental Procedure}

Chemical composition of hot rolled steel sheets used in the experiment are shown in Table 1. Steels 1 and 2 were from BOF and they were hot rolled at Fukuyama Works with the coiling temperature of $700^{\circ}$ C. Steels 3, 4 and 5 were experimental steels melted with a vacuum furnace, and were hot rolled with a laboratory mill and subjected to a treatment simulating a coiling at $700^{\circ} \mathrm{C}$. These steels were cold rolled by $75 \%$ and annealed by the heat cycles indicated in Fig. 3 by means of salt baths. The annealed samples were cut along the transverse direction, and temper rolled by $1 \%$ with a laboratory mill. Tensile testing were undertaken for samples just after temper rolling, those after artificial aging treatment at $38^{\circ} \mathrm{C}$ for 8 days, and those after $2 \%$ pre-straining and subsequent aging treatment at $170^{\circ} \mathrm{C}$ for $20 \mathrm{~min}$. Determination of $\bar{r}$-value was made after $15 \%$ straining of tensile specimen taken in the longitudinal, transverse and diagonal directions.

\section{Results and Discussion}

Typical microstructures and mechanical properties of the products are shown in Photo. 1, Tables 2 and
3, respectively. Photograph 1 shows that the volume fraction of second phase martensite decreases with lowering $\mathcal{T}_{2}$, and the morphology of the martensite tends to take a form of cluster because ferrite was also formed from a part of a lump of austenite in the course of slow phase transformation during air cooling from $T_{1}$ to $T_{2}$. This change of martensite morphology becomes more remarkable when the difference between $T_{1}$ and $T_{2}$ is larger.

Examples of mechanical properties of annealed steel sheets are shown in Table 2. In the table, we can find that only Steel 2 satisfies the material requirements :

Yield strength : lower than $24 \mathrm{kgf} / \mathrm{mm}^{2}$.

Total elongation: more than $40 \%$.

$\bar{r}$-value : higher than 1.5 .

Yield strength after 2\% straining and subsequent baking : more than $39 \mathrm{kgf} / \mathrm{mm}^{2}$.

Table 3 shows the relationship between the annealing cycles and the mechanical properties of Steel 2. From the table, it is recognized that the yield strengths after rolling are lower than $24 \mathrm{kgf} / \mathrm{mm}^{2}$ and the total elongations are more than $40 \%$ at all annealing cycles. Moreover we can confirm that the products are almost free from strain at room temperature while having a bake hardenability; the absence of yield point elongation after the aging at $38^{\circ} \mathrm{C}$ for 8 days clearly indicates that the hard second phase acts to suppress the reappearance of yield point elongation as expected. However, with respect to the $\bar{r}$-value, the level of 1.5 is cleared only when $T_{1}$ is $850^{\circ} \mathrm{G}$ and $T_{3}$ is $350^{\circ} \mathrm{G}$.

The influences of the annealing conditions, $T_{1}, T_{2}$ and $T_{3}$, on the yield strength, total elongation, $\vec{r}$-value and bake hardening, will be discussed as follows.

Figure 4 shows the influence of the annealing conditions, $T_{1}$ and $T_{3}$, on the yield strength and total elongation after temper rolling by the different marks. It is found that the yield strength and the elongation

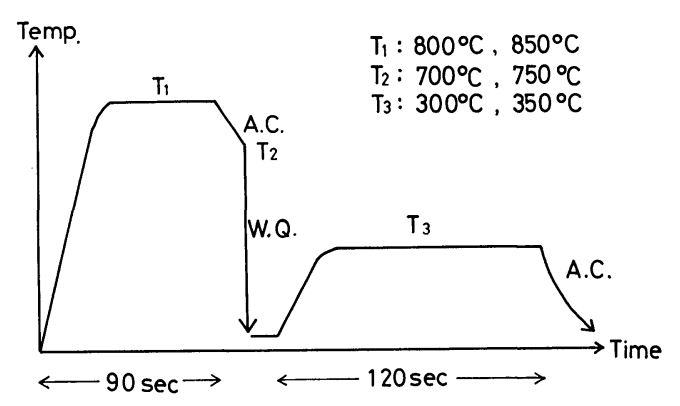

Fig. 3. Heat treatment cycles.

Table 1. Chemical composition and thicknesses of samples.

\begin{tabular}{c|ccccccc|cc}
\hline \multirow{2}{*}{$\begin{array}{c}\text { Steel } \\
\text { No. }\end{array}$} & \multicolumn{7}{|c}{ Composition (wt\%) } & \multicolumn{2}{c}{ Thickness (mm) } \\
\cline { 2 - 10 } & $\mathrm{C}$ & $\mathrm{Si}$ & $\mathrm{Mn}$ & $\mathrm{P}$ & $\mathrm{S}$ & sol. Al & $\mathrm{N}$ & Hot & Cold \\
\hline 1 & 0.04 & 0.01 & 0.16 & 0.010 & 0.015 & 0.046 & 0.0048 & 2.8 & 0.6 \\
2 & 0.04 & tr. & 0.18 & 0.018 & 0.020 & 0.030 & 0.0053 & 2.8 & 0.6 \\
3 & 0.03 & tr. & 0.16 & 0.018 & 0.003 & 0.042 & 0.0039 & 3.2 & 0.8 \\
4 & 0.03 & tr. & 0.16 & 0.037 & 0.003 & 0.029 & 0.0026 & 3.2 & 0.8 \\
5 & 0.03 & tr. & 0.16 & 0.054 & 0.003 & 0.038 & 0.0029 & 3.2 & 0.8 \\
\hline
\end{tabular}



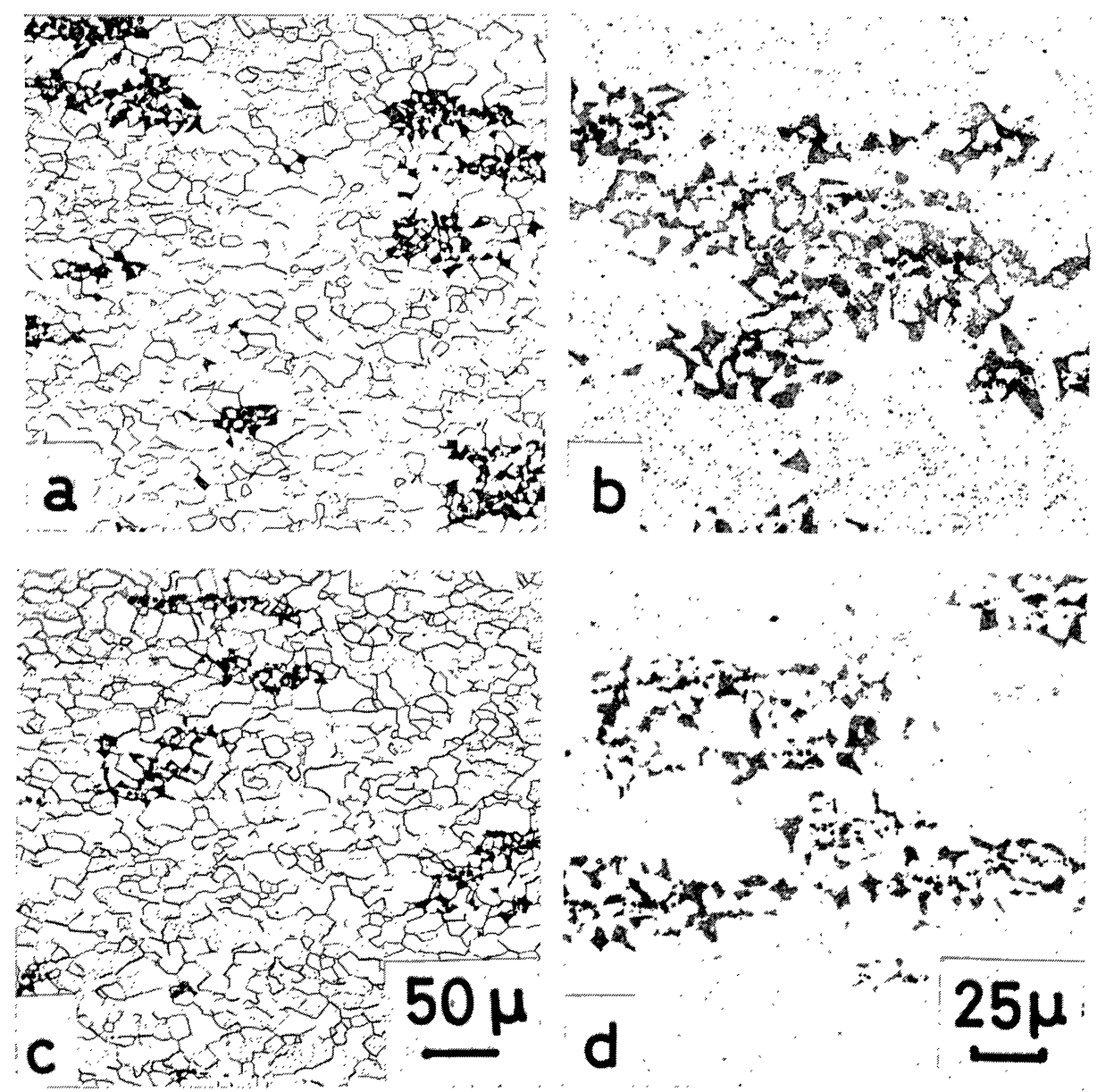

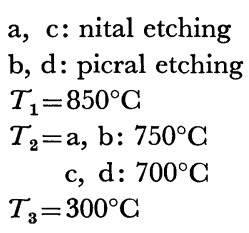

Photo. 1. Microstructures of Steel 1.

Table 2. Examples of mechanical properties*.

\begin{tabular}{|c|c|c|c|c|c|c|c|c|c|c|c|c|c|}
\hline \multirow{3}{*}{$\begin{array}{l}\text { Steel } \\
\text { No. }\end{array}$} & \multirow{3}{*}{$\begin{array}{c}t \\
(\mathrm{~mm})\end{array}$} & \multicolumn{9}{|c|}{ After temper rolling ( $1 \%)$} & \multicolumn{3}{|c|}{ After pre-strained and baking** } \\
\hline & & \multirow{2}{*}{$\begin{array}{l}\text { YS } \\
(\mathrm{kgf} / \\
\left.\mathrm{mm}^{2}\right)\end{array}$} & \multirow{2}{*}{$\begin{array}{l}\text { YPel } \\
\text { (\%) }\end{array}$} & \multirow{2}{*}{$\begin{array}{c}\mathrm{TS} \\
(\mathrm{kgf} / \\
\left.\mathrm{mm}^{2}\right)\end{array}$} & \multirow{2}{*}{$\begin{array}{l}\text { T.El } \\
(\%)\end{array}$} & \multirow{2}{*}{$\left(\begin{array}{c}n \\
(6 \sim 12 \%)\end{array}\right.$} & \multicolumn{4}{|c|}{$r$-value } & \multirow{2}{*}{$\underset{\left(\mathrm{kgf} / \mathrm{mm}^{2}\right)}{\Delta \sigma_{\mathrm{WH}}}$} & \multirow{2}{*}{$\begin{array}{c}\Delta \sigma_{\mathrm{BH}} \\
\left(\mathrm{kgf} / \mathrm{mm}^{2}\right)\end{array}$} & \multirow{2}{*}{$\underset{\left(\mathrm{kgf} / \mathrm{mm}^{2}\right)}{\Delta \sigma_{\mathrm{T}}}$} \\
\hline & & & & & & & $0^{\circ}$ & $45^{\circ}$ & $90^{\circ}$ & $\bar{r}$ & & & \\
\hline 1 & 0.6 & 23.5 & 0 & 35.6 & 43.9 & 0.198 & 1.57 & 1.32 & 1.74 & 1.49 & 3.5 & 4.0 & 7.5 \\
\hline 2 & 0.6 & 21.5 & 0 & 34.6 & 42.9 & 0.207 & 1.65 & 1.28 & 1.90 & 1.53 & 3.9 & 4.7 & 8.6 \\
\hline 3 & 0.8 & 23.1 & 0 & 34.0 & 41.3 & 0.202 & 1.43 & 1.20 & 1.81 & 1.41 & 5.1 & 3.5 & 8.6 \\
\hline 4 & 0.8 & 24.9 & 0 & 37.2 & 41.4 & 0.205 & 1.49 & 1.20 & 1.82 & 1.43 & 4.2 & 5.7 & 9.9 \\
\hline 5 & 0.8 & 23.8 & 0 & 35.5 & 40.7 & 0.208 & 1.49 & 1.20 & 1.83 & 1.43 & 4.5 & 4.9 & 9.4 \\
\hline
\end{tabular}

* JIS No. 5 test piece, transverse direction. $T_{1}: 850^{\circ} \mathrm{C} . T_{2}: 700^{\circ} \mathrm{C} . T_{3}: 350^{\circ} \mathrm{C}$.

** $\Delta \sigma_{\mathrm{WH}}$ : The increment of yield strength due to $2 \%$ tensile strain.

$\Delta \sigma_{\mathrm{BH}}$ : The increment of flow stress due to baking for the $2 \%$ pre-strained material at $170^{\circ} \mathrm{C}$ for $20 \mathrm{~min}$.

$\Delta \sigma_{\mathrm{T}}$ : The increment of yield strength after $2 \%$ pre-straining and subsequent baking at $170^{\circ} \mathrm{C}$ for $20 \mathrm{~min}$.

$$
\Delta \sigma_{\mathrm{T}}=\Delta \sigma_{\mathrm{WH}}+\Delta \sigma_{\mathrm{BH}}
$$

for $350^{\circ} \mathrm{C}$ tempering temperature is better than those for $300^{\circ} \mathrm{C}$ as a whole. The effect of $T_{3}$ on these properties is larger than $T_{1}$. This means that these properties are mainly influenced by solid solution hardening of carbon rather than grain size.

Figure 5 shows the influence of the annealing conditions, $T_{1}$ and $T_{2}$, on the yield strength after temper rolling and the $\bar{r}$-value by the different marks. In this figure, there are only three cases which satisfy the requirements of yield strength lower than $24 \mathrm{kgf} /$ $\mathrm{mm}^{2}$ and $\bar{r}$-value larger than 1.5. The $T_{1}$ of these three cases is $850^{\circ} \mathrm{C}$, and also the average $\bar{r}$-value of the $850^{\circ} \mathrm{C}$ group is higher than that of $800^{\circ} \mathrm{G}$. The effect of $T_{1}$ on $\bar{r}$-value is mainly due to the grain growth by which the volume of favorable grains to raise $\bar{r}$-value increases.

In case of $850^{\circ} \mathrm{C} T_{1}$, the average yield strength of the $700^{\circ} \mathrm{C}$ group is lower than that of the $750^{\circ} \mathrm{C}$ group. However, in case of $800^{\circ} \mathrm{C} T_{1}$, the two groups show almost the same yield strength. According to optical microstructures, some difference in volume fractions of second phase is observed in the case of $850^{\circ} \mathrm{C}$ but there are not found any differences in the case of $800^{\circ} \mathrm{C}$. Therefore, it may be considered that 
Table 3. Mechanical properties* of Steel 2.

\begin{tabular}{|c|c|c|c|c|c|c|c|c|c|c|c|c|c|}
\hline \multicolumn{3}{|c|}{ Heating temp. } & \multicolumn{6}{|c|}{ After temper rolling $(1 \%)$} & \multicolumn{4}{|c|}{ After $38^{\circ} \mathrm{C} \times 8$ days } & \multirow{2}{*}{$\frac{\text { A.B. }{ }^{* *}}{\begin{array}{c}\Delta \sigma_{\mathrm{T}} \\
\left(\mathrm{kgf} / \mathrm{mm}^{2}\right)\end{array}}$} \\
\hline $\begin{array}{c}T_{1} \\
\left({ }^{\circ} \mathrm{C}\right)\end{array}$ & $\begin{array}{c}T_{2} \\
\left({ }^{\circ} \mathrm{C}\right)\end{array}$ & $\begin{array}{c}T_{3} \\
\left({ }^{\circ} \mathrm{C}\right)\end{array}$ & $\underset{\left(\mathrm{kgf} / \mathrm{mm}^{2}\right)}{\mathrm{YS}}$ & $\begin{array}{l}\text { YPel } \\
(\%)\end{array}$ & $\underset{\left(\mathrm{kgf} / \mathrm{mm}^{2}\right)}{\mathrm{TS}}$ & $\begin{array}{l}\text { T.El } \\
(\%)\end{array}$ & $\begin{array}{c}n \\
(6 \sim 12 \%)\end{array}$ & $\bar{r}$ & $\underset{\left(\mathrm{kgf} / \mathrm{mm}^{2}\right)}{\mathrm{YS}}$ & $\begin{array}{l}\text { YPel } \\
(\%)\end{array}$ & $\underset{\left(\mathrm{kgf} / \mathrm{mm}^{2}\right)}{\mathrm{TS}}$ & $\begin{array}{l}\text { T.El } \\
(\%)\end{array}$ & \\
\hline \multirow{4}{*}{850} & \multirow{2}{*}{750} & 350 & 22.6 & 0 & 36.1 & 40.7 & 0.187 & 1.55 & 22.3 & 0 & 36.0 & 40.3 & 8.6 \\
\hline & & 300 & 22.8 & 0 & 36.7 & 45.1 & 0.207 & 1.46 & 23.6 & 0 & 36.7 & 39.8 & 9.6 \\
\hline & \multirow{2}{*}{700} & 350 & 21.5 & 0 & 34.6 & 42.9 & 0.207 & 1.53 & 22.0 & 0 & 34.8 & 42.0 & 8.6 \\
\hline & & 300 & 21.6 & 0 & 35.2 & 43.0 & 0.205 & 1.49 & 22.3 & 0 & 35.1 & 42.2 & 9.6 \\
\hline \multirow{4}{*}{800} & \multirow{2}{*}{750} & 350 & 22.0 & 0 & 35.8 & 41.5 & 0.212 & 1.38 & 22.4 & 0 & 35.2 & 41.0 & 9.0 \\
\hline & & 300 & 22.1 & 0 & 35.9 & 40.5 & 0.207 & 1.41 & 23.3 & 0 & 35.9 & 40.0 & 10.2 \\
\hline & \multirow{2}{*}{700} & 350 & 22.1 & 0 & 34.8 & 42.7 & 0.218 & 1.38 & 23.4 & 0 & 34.8 & 40.1 & 7.7 \\
\hline & & 300 & 21.5 & 0 & 34.9 & 42.1 & 0.210 & 1.44 & 26.3 & 0 & 35.1 & 41.0 & 9.4 \\
\hline
\end{tabular}

JIS No. 5 test piece, transverse direction, $0.6 \mathrm{~mm}$ thickness.

** After baking. $\Delta \sigma_{\mathrm{T}}$ : the increment of yield strength after $2 \%$ pre-straining and subsequent baking at $170^{\circ} \mathrm{C}$ for $20 \mathrm{~min}$.

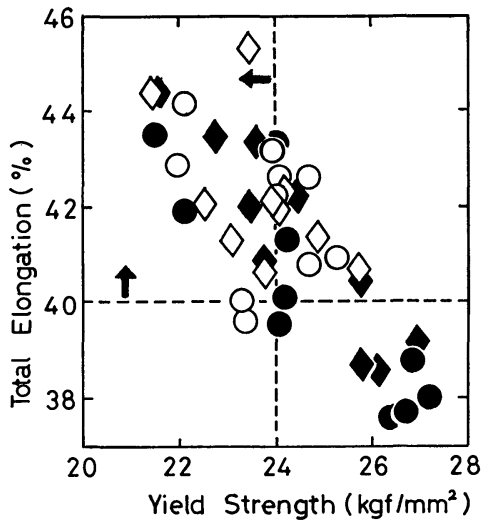

The arrows and the dashed lines show the range of the target properties. The elongation are corrected to a thickness of $0.8 \mathrm{~mm}$ by Oliver's equation.

$T_{2}: 700^{\circ}$ and $750^{\circ} \mathrm{G}$

$\diamond: T_{1}, 850^{\circ} \mathrm{C} ; T_{3}, 350^{\circ} \mathrm{C}$

•: $T_{1}, 850^{\circ} \mathrm{C} ; T_{3}, 300^{\circ} \mathrm{C}$

○: $T_{1}, 800^{\circ} \mathrm{G} ; T_{3}, 350^{\circ} \mathrm{G}$

-: $T_{1}, 800^{\circ} \mathrm{C} ; T_{3}, 300^{\circ} \mathrm{C}$

Fig. 4. Influence of the annealing conditions, $T_{1}$ and $T_{3}$, on the yield strength and the total elongation after temper rolling.

the distribution of carbon in austenite is not homogeneous at $800^{\circ} \mathrm{C}$ because of the coarse carbide.

Figure 6 shows the influence of the annealing conditions, $T_{2}$ and $T_{3}$, on the yield strength after temper rolling and the increment of yield strength after $2 \%$ pre-straining and subsequent baking at $170^{\circ} \mathrm{C}$ for 20 min. The upper right side of dashed oblique line in this figure is the range where the yield strength after $2 \%$ straining and subsequent baking at $170^{\circ} \mathrm{C}$ is higher than $30 \mathrm{kgf} / \mathrm{mm}^{2}$.

Namely, the range between the two dashed lines satisfies the requirements for yield strengths before and after press forming. It is found that there are several experimental results in the range and their majority belongs to the $700^{\circ} \mathrm{C}$ group. Therefore, it can be determined that $700^{\circ} \mathrm{C}$ is better quenching temperature. From the same point of view, the tempering condition to meet the range can not be determined.

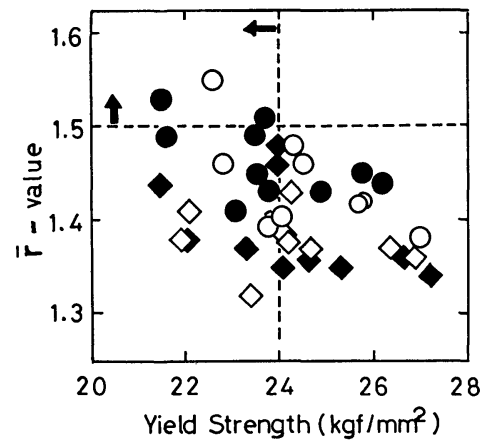

The arrows and the dashed lines show the range of the target properties.

$T_{3}: 300^{\circ}$ and $350^{\circ} \mathrm{C}$

○: $T_{1}, 850^{\circ} \mathrm{C} ; T_{2}, 750^{\circ} \mathrm{C}$

๑: $T_{1}, 850^{\circ} \mathrm{C} ; T_{2}, 700^{\circ} \mathrm{C}$

$\diamond: T_{1}, 800^{\circ} \mathrm{G} ; T_{2}, 750^{\circ} \mathrm{C}$

$\bullet: T_{1}, 800^{\circ} \mathrm{C} ; T_{2}, 700^{\circ} \mathrm{C}$

Fig. 5. Influence of the annealing conditions, $T_{1}$ and $T_{2}$, on the yield strength after temper rolling and the $\bar{r}$-value.

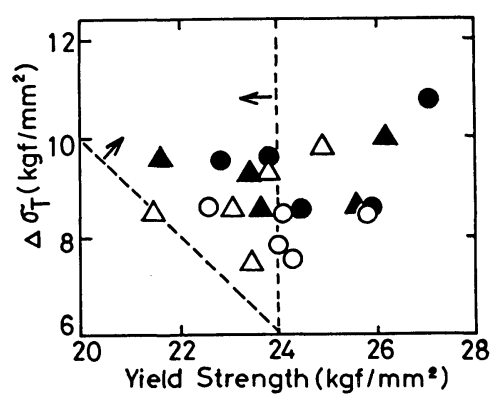

The arrows and the dashed lines show the range of the target properties.

$T_{1}: 850^{\circ} \mathrm{G}$

O: $T_{2}, 750^{\circ} \mathrm{C} ; T_{3}, 350^{\circ} \mathrm{G}$

๑: $T_{2}, 750^{\circ} \mathrm{C} ; T_{3}, 300^{\circ} \mathrm{C}$

$\triangle: T_{2}, 700^{\circ} \mathrm{C} ; T_{3}, 350^{\circ} \mathrm{C}$

$\Delta$ : $T_{2}, 700^{\circ} \mathrm{G} ; T_{3}, 300^{\circ} \mathrm{C}$

Fig. 6. Influence of the annealing condition, $T_{2}$ and $T_{3}$, on the yield strength after temper rolling and the increment, $\Delta \sigma_{\mathrm{T}}$, of yield strength after $2 \%$ prestraining and subsequent baking at $170^{\circ} \mathrm{C}$ for 20 min. 
Table 4. Mechanical properties* of the steel sheets of the mill trial.

\begin{tabular}{|c|c|c|c|c|c|c|c|c|c|c|c|c|c|c|}
\hline \multirow{2}{*}{$\begin{array}{l}\text { CAL } \\
\text { Cycle }\end{array}$} & \multicolumn{7}{|c|}{ After temper rolling ( $1 \%)$} & \multicolumn{4}{|c|}{ After $38^{\circ} \mathrm{C} \times 8$ days } & \multicolumn{3}{|c|}{$\begin{array}{l}\text { After } 2 \% \text { pre-straining } \\
\text { and baking** }\end{array}$} \\
\hline & $\stackrel{t}{t}(\mathrm{~mm})$ & $\begin{array}{l}\mathrm{YS} \\
(\mathrm{kgf} / \\
\left.\mathrm{mm}^{2}\right)\end{array}$ & $\begin{array}{l}\text { YPel } \\
(\%)\end{array}$ & $\begin{array}{c}\mathrm{TS} \\
(\mathrm{kgf} / \\
\left.\mathrm{mm}^{2}\right)\end{array}$ & $\begin{array}{l}\text { T.EI } \\
(\%)\end{array}$ & $\begin{array}{c}n \\
(10 \sim \\
20 \%)\end{array}$ & $\bar{r}$ & $\begin{array}{c}\mathrm{YS} \\
(\mathrm{kgf} / \\
\left.\mathrm{mm}^{2}\right)\end{array}$ & $\begin{array}{l}\text { YPel } \\
(\%)\end{array}$ & $\begin{array}{l}\mathrm{TS} \\
(\mathrm{kgf} / \\
\left.\mathrm{mm}^{2}\right)\end{array}$ & $\begin{array}{l}\text { T.El } \\
(\%)\end{array}$ & $\begin{array}{c}\Delta \sigma_{\mathrm{WH}} \\
(\mathrm{kgf} / \\
\left.\mathrm{mm}^{2}\right)\end{array}$ & $\begin{array}{l}\Delta \sigma_{\mathrm{BH}} \\
(\mathrm{kgf} / \\
\left.\mathrm{mm}^{2}\right)\end{array}$ & $\begin{array}{l}\Delta \sigma_{\mathrm{T}} \\
(\mathrm{kgf} / \\
\left.\mathrm{mm}^{2}\right)\end{array}$ \\
\hline 1 & 0.7 & 23.9 & 0 & 37.0 & 39.5 & 0.170 & 1.62 & 24.0 & 0 & 37.5 & 37.3 & 5.3 & 5.4 & 10.7 \\
\hline 2 & 0.7 & 22.6 & 0 & 36.2 & 42.9 & 0.187 & 1.61 & 22.4 & 0 & 35.8 & 41.9 & 5.2 & 3.8 & 9.0 \\
\hline
\end{tabular}

Chemical compositions (wt\%): C 0.04, Si 0.02, Mn 0.21, P 0.015, S 0.017, sol. Al 0.052, N 0.0027.

Hot rolling conditions: Finishing temperature: $870^{\circ} \mathrm{C}$. Coiling temperature: $700^{\circ} \mathrm{C}$. Thickness : $3.2 \mathrm{~mm}$.

Annealing conditions : Cycle 1: $T_{1}=850^{\circ} \mathrm{C}, T_{2}=700^{\circ} \mathrm{C}, T_{3}=280^{\circ} \mathrm{C}$. Cycle 2: $T_{1}=850^{\circ} \mathrm{C}, T_{2}=720^{\circ} \mathrm{C}, T_{3}=350^{\circ} \mathrm{C}$.

* JIS No. 5 test piece (gage length : $50 \mathrm{~mm}$, width : $25 \mathrm{~mm}$ ), transverse direction.

** $170^{\circ} \mathrm{C}$ for $20 \mathrm{~min}$.

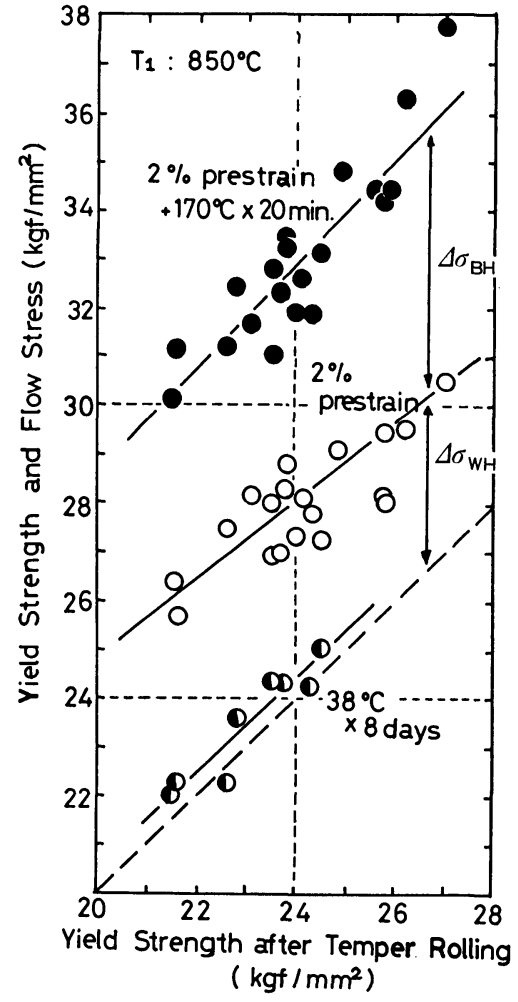

Fig. 7. Work hardening, bake hardening and aging behavior as a function of yield strength after temper rolling.

Figure 7 shows the yield strengths after artificial aging treatment at $38^{\circ} \mathrm{C}$ for 8 days, the flow stress at $2 \%$ strain and the yield strength after subsequent aging treatment at $170^{\circ} \mathrm{C}$ for $20 \mathrm{~min}$ as a function of yield strength after temper rolling. The following can be recognized from Fig. 7 :

(1) The rise of the yield strength after aging at $38^{\circ} \mathrm{G}$ is very small.

(2) The work hardening $\Delta \sigma_{\mathrm{WH}}$ is nearly equal to bake hardening $\Delta \sigma_{\mathrm{BH}}$ in the samples of $24 \mathrm{kgf} / \mathrm{mm}^{2}$ yield strength.

(3) The sum of $\Delta \sigma_{\mathrm{WH}}$ and $\Delta \sigma_{\mathrm{BH}}$ is about $9 \mathrm{kgf} / \mathrm{mm}^{2}$. Therefore, it is certain that the steel sheets with yield strength of about $22 \mathrm{kgf} / \mathrm{mm}^{2}$ before press forming have yield strength of $30 \mathrm{kgf} / \mathrm{mm}^{2}$ after press forming and paint baking.

The above results indicate that the desirable annealing temperature $T_{1}$, quenching temperature $T_{2}$ and tempering temperature $T_{3}$ are $850^{\circ} \mathrm{C}, 700^{\circ} \mathrm{C}$ and $350^{\circ} \mathrm{C}$, respectively.

\section{Results of Manufacturing Tests and Con- clusion}

On the basis of the above experimental results, manufacturing tests have been carried out at Fukuyama Works by use of the steel similar to Steel 2 of Table 1. The results are summarized in Table 4 . Temperatures corresponding to $T_{1}, T_{2}$ and $T_{3}$ are indicated in the footnotes of the Table 4, although the annealing cycles in the manufacturing line are not the same as the cycles shown in Fig. 3 in a strict sense. The same effects of the temperature as observed in the laboratory test are confirmed by the data in Table 4 .

This leads to the conclusion that the cold rolled dual-phase steel sheets having the following mechanical properties can be produced by using leaner alloying compositions:

Yield strength : lower than $24 \mathrm{kgf} / \mathrm{mm}^{2}$.

Total elongation: larger than $40 \%$.

$\bar{r}$-value $\quad:$ higher than 1.5.

Yield strength after $2 \%$ straining and subsequent baking : higher than $30 \mathrm{kgf} / \mathrm{mm}^{2}$.

Anti-aging properties: the complete suppression of the re-appearance of yield point elongation at room temperature.

Following the aim of automobile makers, the applicability of this type of product to automobile outer body panels and inner body pannels should be further investigated.

\section{REFERENCES}

1) T. Shimomura, M. Yoshida, M. Sakoh and K. Matsudo: Mem. Sci. Rev. Met., 77 (1980), 465.

2) H. Kubotera, K. Nakaoka, Y. Hashimoto, K. Araki and A. Nishimoto: Tetsu-to-Hagané, 55 (1969), S539.

3) K. Nakaoka, K. Araki and O. Kimpara: Tetsu-to-Hagané, 62 (1976), A139.

4) K. Nakaoka, K. Araki, K. Kurihara and S. Fukunaka: Tetsu-to-Hagané, 61 (1975), S571.

5) H. Kubotera, K. Nakaoka, K. Araki, K. Watanabe and K. Iwase: Tetsu-to-Hagané, 62 (1976), 846. 